\title{
Single-dose dexamethasone as an adjuvant therapy for sore throat in adults: A cohort study
}

\author{
Dong-gon Hyun ${ }^{1}$ and Yoon jung Jang ${ }^{2}$ \\ ${ }^{1}$ Victory Hospital \\ ${ }^{2}$ Asan Medical Center
}

July 23, 2020

\begin{abstract}
Background: Several studies have suggested that a short course of corticosteroid therapy with the standard care increases complete sore throat resolution in 24 hours, however, corticosteroids are yet to be a common prescription for acute sore throat patients. This study aimed to confirm the effectiveness and safety of adjuvant corticosteroid treatment with standard care, by investigating the treatment response and prognostic factors associated with increased symptom resolution. Methods: This retrospective study included 40 patients with acute sore throat symptoms. The degree of sore throat was checked using the manner of Numeral Rating Scale (NRS). Patients were orally or intramuscularly administered a single dose of $10 \mathrm{mg}$ of dexamethasone as an adjuvant therapy with conventional treatments. Treatment response was stratified according to the degree of resolution of sore throat at 24 hours. Results: Of the 40 patients involved, $27(67.5 \%)$ showed more than $50 \%$ reduction in NRS in 24 hours. On the contrary, 9 patients (22.5\%) experienced less than $50 \%$ sore throat resolution, while 4 (10\%) reported no significant pain relief. Multivariable logistic model controlling for significant covariables revealed that cough (OR, 0.02; $95 \%$ confidence interval, $0.01-0.40 ; \mathrm{p}=0.01$ ) was an independent factor for predicting treatment response. In addition, post-hoc analysis showed a negative association between treatment response and the degree of cough (86.7\% in no cough vs. $75.0 \%$ in intermittent cough vs. $47.1 \%$ in persistent cough, $\mathrm{P}=0.023)$. Additionally, none of the patients experienced infection complications. Conclusions: A single-dose dexamethasone as an adjuvant therapy with standard care is an effective and safe strategy for patients presenting with acute sore throat in primary care clinics. Specifically, the efficacy of corticosteroid treatment for sore throat was higher in patients without cough.
\end{abstract}

\section{What's already known about this topic?}

- One of the most common presenting complaints among patients in outpatient care clinics is sore throat.

- Non-steroidal anti-inflammatory drugs or acetaminophen as the main management strategy provide insufficient pain relief in many cases.

- Several studies have suggested that a short course of corticosteroid therapy with the standard care increases complete sore throat resolution in 24 hours.

\section{What does this article add?}

- Adjuvant dexamethasone resulted in a high proportion of patients reporting sufficient response in sore throat patients.

- Cough was significantly negatively associated with treatment response.

\section{Introduction}

One of the most common presenting complaints among patients in outpatient care clinics is sore throat [1], resulting in approximately $5 \%$ of all outpatients visits [2]. Bacterial- or viral-induced acute pharyngotonsillitis is the cause of more than $75 \%$ of sore throats [3]. Several national guidelines recommend pain relief with 
non-steroidal anti-inflammatory drugs (NSAIDs) or acetaminophen as the main management strategy [46]. However, these drugs provide insufficient pain relief in many cases. Although less than $10 \%$ of adult pharyngotonsillitis are caused by bacteria and the risk of suppurative complications is low, primary care physicians usually prescribe antibiotics, despite their limited symptomatic benefit [7-9].

The need to reduce pain relief consumption has led to a focus on alternative treatment with corticosteroids [10]. Corticosteroids are potent anti-inflammatory mediators. Results of several randomized control trials have suggested that short courses of corticosteroid therapy provide symptomatic relief benefits to sore throat patients, with no safety concerns [11-13]. A systemic review revealed that patients treated with a single steroid dose were more likely to experience complete sore throat resolution within 24 hours, in a setting of antibiotic use in both the steroid and placebo groups [14]. Recently, another primary care randomized trial showed that oral corticosteroid administration unaccompanied by immediate antibiotic use increased the proportion of patients with sore throat resolution within 48 hours [15]. Despite this new potential practice changing evidence, corticosteroid prescribing remains uncommon and the previous conventional treatments such as antibiotics, remain the norm [16].

This study confirmed the effectiveness and safety of adjuvant corticosteroid treatment with standard care and provided evidence for the wide application of this new strategy in primary care, by investigating treatment outcomes in sore throat adults 18 years or older and the prognostic factors associated with increased symptom resolution.

\section{Materials and methods}

\section{Study Design and Patients}

This retrospective study included 40 military patients presenting to the Victory hospital of the 15th infantry division of the army with acute sore throat symptoms from May 1 to December 31, 2019. Included patients were aged 18 years or older, prescribed a single dose of oral or intramuscular dexamethasone, and hospitalized for at least 1 day in the short-term care center of the hospital. Patients suspected to have infection complications, determined via a lung sound crackle, chest X-ray haziness, peritonsillar abscess, or thrombophlebitis in the internal jugular vein, were excluded. This study was approved by the Institutional Review Board (IRB) of the Republic of Korea Army (AFMC-20042-IRB-20-042) and performed in accordance with the amended Declaration of Helsinki. Because this study was a retrospective analysis, the informed consent requirement was waived by the IRB.

\section{Data collection and Procedures}

Baseline clinical features, symptoms, and signs were obtained via a review of the patients' electronic medical records. The degree of sore throat was checked using the manner of Numeral Rating Scale (NRS), ranging from 0 to 10 , where 0 is no pain and 10 is the worst pain imaginable. If radiologic (Chest x-ray) and laboratory tests such as white blood cell counts, were conducted, these data were also collected. Because rapid streptococcal antigen tests were not available at this hospital, it was not performed for any of the patients. Patients were orally or intramuscularly administered a single dose of $10 \mathrm{mg}$ of dexamethasone as an adjuvant therapy with conventional treatment such as anti-pyretics and anti-histamines. The clinician decided to offer antibiotic prescriptions with the usual instruction. All patient treatment prescriptions were recorded.

\section{Treatment response and outcomes}

Treatment response was stratified according to the degree of resolution for sore throat at 24 hours, as reported by the patient via clinician examination; non-responders with no improvement at 24 hours, partial responders with less than $50 \%$ NRS reduction compared with the score at admission, and responders with a more than $50 \%$ change in NRS. The primary outcome was the proportion of responders and the factors associated with response to dexamethasone. The secondary outcomes were as follows: 1) resolution of fever at 24 hours; and 2) Safety of infection after adjuvant dexamethasone. The safety profiles of steroid use-induced infectious disease were collected from patient electronic medical records. 


\section{Statistical analysis}

Descriptive data are expressed as proportions, and continuous variables as mean plus standard deviation. Continuous variables with normal distribution were compared using the paired t-test. Univariate and multivariate logistic regression modelling identified factors associated with treatment response. A final model was constructed using a stepwise method with backward selection; $p$ values $<0.15$ in univariate analysis were set for the entry of variables. The Linear-by-Linear association test was used to analyze trends for categorical variables. Two-sided $p$ values $<0.05$ were considered to indicate significance. All analyses were performed using the SPSS ver. 24.0 (IBM Corporation, USA) software.

\section{Results}

\section{Patient characteristics}

After assessing for eligibility, 40 patients treated with adjuvant dexamethasone and evaluated on the response of sore throat at 24 hours, met the inclusion criteria. Additionally, 21 patients had Chest X-rays and 16 had their complete blood count determined. The baseline characteristics of patients are shown in Table 1. Because of the present study was conducted in a military hospital, all 40 patients were men and their mean age was 21.3 years (standard deviation $[\mathrm{SD}], \pm 1.4$ years). Patients visited the hospital a mean of 3.6 days (SD, \pm 1.2 days) after symptom onset. The mean score of NRS for sore throat at admission was 6.9 (SD, \pm 1.9). The most common symptom was febrile sensation (95.0\%) with mean 38.0 (SD, +- 0.9). Most patients had more than a grade 3 tonsillar swelling $(67.5 \%)$ and tonsillar exudate $(75.0 \%)$. Of the 40 patients, 29 had a modified Centor score of 2 or 3 (72.5\%). Almost every patient received antibiotics (95.0\%); 26 had immediate antibiotics therapy $(66.7 \%)$ and 13 had delayed antibiotics therapy $(33.3 \%)$ due to the absence of the rapid streptococcal antigen test. None of the 21 patients (52.5\%) who had a chest X-ray at admission presented with pneumonia.

\section{Treatment outcomes}

Compared with the score at admission, the NRS for sore throat at 24 hours after admission (mean, $3.0+-$ 1.9) was significantly resolved (Table 2). Of the 40 patients, $24(67.5 \%)$ reported a more than $50 \%$ reduction of NRS in 24 hours, and were classified as responders. On the other hand, 9 patients (22.5\%) experienced less than $50 \%$ resolution of sore throat and $4(10 \%)$ had no significant pain relief. Most patients reported fever resolution at $24(92.5 \%)$ or $48(87.5 \%)$ hours. There were no reports of infection complications according to the patient electronic medical records.

\section{Prognostic factors}

To investigate the prognostic factors associated with treatment response, we conducted a multivariable logistic analysis (Table 3). Although none of variables showed a statistically significant association with treatment response according to the univariate analysis, the multivariable logistic model controlling for significant covariables which had a $p$-value less than 0.15 in the univariate model (duration of symptoms before admission, cough, nausea, and hemoglobin), revealed that cough (OR, 0.02; 95\% confidence interval, $0.01-0.40 ; p=0.01)$ was an independent factor for predicting treatment response.

\section{Correlation between treatment response and cough}

Since the multivariate model showed that cough was associated with treatment response, we conducted an additional analysis for cough (Table 4). We classified cough into 2 groups based on symptoms; some patients had intermittent cough in particular situations or time, especially during sleep at night, while others experienced persistent cough all day. Treatment response showed a negative association with the degree of cough $(86.7 \%$ in no cough vs. $75.0 \%$ in intermittent cough vs. $47.1 \%$ in persistent cough, $P=$ $0.023)$.

\section{Discussion}

In sore throat patients, adjuvant dexamethasone resulted in a high proportion of patients reporting sufficient 
response. Additionally, of all the symptoms, cough was significantly negatively associated with treatment response. Patients presenting with less cough tended to experience higher sore throat resolution. There was no incidence of infection complications in patients. This new treatment strategy seems to be effective and safe.

The criteria for treatment outcome evaluation in the present study was different from those of other studies, as previous studies usually established clinical outcomes as complete resolution at 24 or 48 hours [17]. A recent randomized trial for elucidating the efficacy of dexamethasone without immediate antibiotic use showed that $22.6 \%$ and $35.4 \%$ of patients in the dexamethasone group experienced complete resolution at 24 and 48 hours, respectively, with a risk ratio (RR) of 1.28 at 24 hours and 1.31 at 48 hours [15]. A meta-analysis including both adults and children reported a RR of complete pain resolution of 3.2 at 24 hours and $14 \%$ pain reduction by corticosteroids at 24 hours [14]. However, the criteria of clinical outcomes in this study was divided into three groups: non-responder, partial responder, and responder, because the study never aimed to compare the effects with or without steroid, but to describe the response according to the adjuvant steroid. Additionally, although only $2(5 \%)$ of the patients in this study experienced complete resolution at 24 hours, $30(75.0 \%)$ reported with an NRS of 2,3 , or 4 at 24 hours. Since a less than 4 NRS score generally indicates mild symptoms, the response in this study was enough to prove the efficacy of dexamethasone [18].

In the present study, cough was negatively associated with the response to corticosteroid treatment. After reviewing the symptoms in the medical record, patients with cough were stratified into two categories: those with intermittent cough, especially during sleep at night, and those with persistent cough, regardless of the specific condition. When we analyzed the treatment response according to the degree of cough, there was a significant difference in sore throat resolution between cough type. Although this result has not been evaluated in detail by other studies, we had a few hypotheses for the reason of the association between cough and treatment response. Several mechanisms are responsible for cough reflexes in the course of pharyngitis [19-21]. Corticosteroids suppress pro-inflammatory mediators, which could have decreased cough induced by these mediators [22]. However, steroid use might have been insufficient for the inhibition of persistent cough resulting from inflammation-induced nerve injury [23]. We believe that further studies can help elucidate this mechanism.

Because this study was retrospective, antibiotic use was decided by the clinician. Although several studies showed that most adults with sore throat do not need antibiotics, they are usually offered to adult sore throat patients [7]. Antibiotic use can reduce the incidence of suppurative complications and provide additional benefits to some patients with bacterial infections [24]. However, a recent study demonstrated that steroid use without immediate antibiotic use could improve sore throat symptom recovery [15]. Also, several studies have reported viruses as the cause of purulent or large tonsils in most patients [24,25]. The rapid streptococcal antigen test was unavailable at the primary clinics in which the present study was conducted and most of the included patients had a modified Centor score of 2 or 3 . Therefore, almost all patients in this study were treated with immediate or delayed antibiotics due to the fear of bacterial tonsillitis. To reduce antibiotic use for sore throat, the evidence for adjuvant steroids should be collected continually and made widely known.

This study had several limitations. First, the small sample size could make its results less significant and might have prevented adverse event detection. However, we had $100 \%$ of the sore throat score data and collected information on variable symptoms, treatment options, and signs upon physical examination, to aid our search for prognostic factors by applying these variables to the multivariate model. Secondly, the included patients were all young men without comorbidity. There have been no studies that recruited patients with comorbidities [14,17]. Since corticosteroid-induced infection complications may be more common in patients with comorbidities, uncertainty remains about the prescribing of steroids to those presenting in primary clinics. Thus, future studies in patients with comorbidities are needed. Despite these limitations, the study has many strengths. To the best of our knowledge, this is the first study to evaluate the benefits of oral corticosteroids for Korean sore throat patients. We also analyzed the prognostic factor associated with treatment response, which could help in the selection of a target group of patients who would benefit from this treatment strategy, reducing unnecessary corticosteroid use. 


\section{Conclusion}

A single-dose dexamethasone as an adjuvant therapy with standard care is an effective and safe strategy for patients presenting to primary care clinics with acute sore throat. Specifically, the corticosteroid treatment was more efficacious in patients without cough. Therefore, it is time to switch to this new treatment strategy.

\section{Acknowledgements}

This study was supported by the University of Ulsan College of Medicine. Editorial support in the form of writing assistance, collation of authors comments, and grammatical editing was provided by the Scientific Publications Team of the Asan Medical Center. In addition, the Asan Medical Library supported the preparation of tables and references.

\section{Conflict of interest}

No potential conflict of interest relevant to this article was reported.

\section{References}

[1] Petersen I, Johnson AM, Islam A, Duckworth G, Livermore DM, Hayward AC. Protective effect of antibiotics against serious complications of common respiratory tract infections: retrospective cohort study with the UK General Practice Research Database. BMJ. 2007;335:982.https://doi.org/10.1136/bmj.39345.405243.BE

[2] Principi N, Bianchini S, Baggi E, Esposito S. No evidence for the effectiveness of systemic corticosteroids in acute pharyngitis, community-acquired pneumonia and acute otitis media. Eur. J. Clin. Microbiol. Infect. Dis. 2013;32:151-160.https://doi.org/10.1007/s10096-012-1747-y

[3] Anjos LM, Marcondes MB, Lima MF, Mondelli AL, Okoshi MP. Streptococcal acute pharyngitis. Rev. Soc. Bras. Med. Trop. 2014;47:409-413.https://doi.org/10.1590/0037-8682-0265-2013

[4] Shulman ST, Bisno AL, Clegg HW, Gerber MA, Kaplan EL, Lee G, et al. Clinical practice guideline for the diagnosis and management of group A streptococcal pharyngitis: 2012 update by the Infectious Diseases Society of America. Clin. Infect. Dis. 2012;55:e86-102.https://doi.org/10.1093/cid/cis629

[5] ESCMID Sore Throat Guideline Group, Pelucchi C, Grigoryan L, Galeone C, Esposito S, Huovinen $\mathrm{P}$, et al. Guideline for the management of acute sore throat. Clin. Microbiol. Infect. 2012;18 Suppl 1:1-28.https://doi.org/10.1111/j.1469-0691.2012.03766.x

[6] Centre for Clinical Practice at NICE (UK). Respiratory tract infections - antibiotic prescribing: prescribing of antibiotics for self-limiting respiratory tract infections in adults and children in primary care. London: National Institute for Health and Clinical Excellence; 2008.

[7] Barnett ML, Linder JA. Antibiotic prescribing to adults with sore throat in the United States, 1997-2010. JAMA Intern. Med. 2014;174:138-140.https://doi.org/10.1001/jamainternmed.2013.11673

[8] Gulliford MC, Dregan A, Moore MV, Ashworth M, Staa TV, McCann G, et al. Continued high rates of antibiotic prescribing to adults with respiratory tract infection: survey of 568 UK general practices. BMJ Open. 2014;4:e006245.https://doi.org/10.1136/bmjopen-2014-006245

[9] Spinks A, Glasziou PP, Del Mar CB. Antibiotics for sore throat. Cochrane Database Syst. Rev. 2013:CD000023.https://doi.org/10.1002/14651858.CD000023.pub4

[10] Olympia RP, Khine H, Avner JR. Effectiveness of oral dexamethasone in the treatment of moderate to severe pharyngitis in children. Arch. Pediatr. Adolesc. Med. 2005;159:278282.https://doi.org/10.1001/archpedi.159.3.278

[11] Kiderman A, Yaphe J, Bregman J, Zemel T, Furst AL. Adjuvant prednisone therapy in pharyngitis: a randomised controlled trial from general practice. Br. J. Gen. Pract. 2005;55:218-221. 
[12] Tasar A, Yanturali S, Topacoglu H, Ersoy G, Unverir P, Sarikaya S. Clinical efficacy of dexamethasone for acute exudative pharyngitis. J. Emerg. Med. 2008;35:363367.https://doi.org/10.1016/j.jemermed.2007.11.029

[13] Bulloch B, Kabani A, Tenenbein M. Oral dexamethasone for the treatment of pain in children with acute pharyngitis: a randomized, double-blind, placebo-controlled trial. Ann. Emerg. Med. 2003;41:601608.https://doi.org/10.1067/mem.2003.136

[14] Hayward G, Thompson MJ, Perera R, Glasziou PP, Del Mar CB, Heneghan CJ. Corticosteroids as standalone or add-on treatment for sore throat. Cochrane Database Syst. Rev. 2012;10:CD008268.https://doi.org/10.1002/14651858.CD008268.pub2

[15] Hayward GN, Hay AD, Moore MV, Jawad S, Williams N, Voysey M, et al. Effect of oral dexamethasone without immediate antibiotics vs placebo on acute sore throat in adults: a randomized clinical trial. JAMA. 2017;317:1535-1543.https://doi.org/10.1001/jama.2017.3417

[16] Hawker JI, Smith S, Smith GE, Morbey R, Johnson AP, Fleming DM, et al. Trends in antibiotic prescribing in primary care for clinical syndromes subject to national recommendations to reduce antibiotic resistance, UK 1995-2011: analysis of a large database of primary care consultations. J. Antimicrob. Chemother. 2014;69:3423-3430.https://doi.org/10.1093/jac/dku291

[17] Sadeghirad B, Siemieniuk RAC, Brignardello-Petersen R, Papola D, Lytvyn L, Vandvik PO, et al. Corticosteroids for treatment of sore throat: systematic review and meta-analysis of randomised trials. BMJ. 2017;358:j3887.https://doi.org/10.1136/bmj.j3887

[18] Williamson A, Hoggart B. Pain: a review of three commonly used pain rating scales. J. Clin. Nurs. 2005;14:798-804.https://doi.org/10.1111/j.1365-2702.2005.01121.x

[19] Keller JA, McGovern AE, Mazzone SB. Translating cough mechanisms into better cough suppressants. Chest. 2017;152:833-841.https://doi.org/10.1016/j.chest.2017.05.016

[20] Capristo C, Rossi GA. Post-infectious persistent cough: pathogenesis and therapeutic options. Minerva Pediatr. 2017;69:444-452.https://doi.org/10.23736/S0026-4946.17.04958-1

[21] Eccles R. Understanding the symptoms of the common cold and influenza. Lancet Infect. Dis. 2005;5:718-725.https://doi.org/10.1016/S1473-3099(05)70270-X

[22] Atkinson SK, Sadofsky LR, Morice AH. How does rhinovirus cause the common cold cough? BMJ Open Respir. Res. 2016;3:e000118.https://doi.org/10.1136/bmjresp-2015-000118

[23] Raeessi MA, Aslani J, Raeessi N, Gharaie H, Karimi Zarchi AA, Raeessi F. Honey plus coffee versus systemic steroid in the treatment of persistent post-infectious cough: a randomised controlled trial. Prim. Care Respir. J. 2013;22:325-330.https://doi.org/10.4104/pcrj.2013.00072

[24] Randel A, Infectious Disease Society of America. IDSA updates guideline for managing group A streptococcal pharyngitis. Am. Fam. Physician. 2013;88:338-340.

[25] Nadeau N, Kimia A, Fine AM. Impact of viral symptoms on the performance of the modified centor score to predict pediatric group A streptococcal pharyngitis. Am. J. Emerg. Med. 2019.https://doi.org/10.1016/j.ajem.2019.10.026

Table 1. Patient characteristics.

\begin{tabular}{ll}
\hline Characteristics & All $(\mathrm{n}=40)$ \\
\hline Mean age, years & $21.3 \pm 1.4$ \\
Male & $40(100.0)$ \\
$\begin{array}{l}\text { Symptoms } \\
\text { Sore throat at admission, NRS }\end{array}$ & $6.9 \pm 1.9$
\end{tabular}




\begin{tabular}{ll}
\hline Characteristics & All $(\mathrm{n}=40)$ \\
\hline Febrile sensation $(\mathrm{n}=39)$ & $38(95.0)$ \\
Body temperature $(\mathrm{n}=39)$, & $38.0 \pm 0.9$ \\
Chills & $36(90.0)$ \\
Myalgia & $33(82.5)$ \\
Headache & $12(30.0)$ \\
Nausea & $12(30.0)$ \\
Vomit & $10(25.0)$ \\
Cough & $25(62.5)$ \\
Sputum & $28(70.0)$ \\
Rhinorrhea & $16(40.0)$ \\
Duration of symptoms before admission, days & $3.6 \pm 1.2$ \\
Physical exam & \\
Tonsilar swelling & \\
Grade 0-2 & $13(32.5)$ \\
Grade 3 & $9(22.5)$ \\
Grade 4 & $18(45.0)$ \\
Tonsilar exudate & $30(75.0)$ \\
Pharyngeal inflammation & $24(60.0)$ \\
Modified Centor score & \\
Score 0-1 & $11(27.5)$ \\
Score 2 & $20(50.0)$ \\
Score 3 & $9(22.5)$ \\
Treatment & \\
Antibiotics & $38(95.0)$ \\
Anti-pyretic agents & $40(100.0)$ \\
Steroid & $40(100.0)$ \\
Anti-histamine agents & $39(97.5)$ \\
Gargle & $16(40.0)$ \\
NSAID lozenge & $15(37.5)$ \\
Laboumonia on Chest X-ray $(\mathrm{n}=21)$ & $0(0.0)$ \\
Hemoglobin, g/dL $(\mathrm{n}=16)$ & $15.0 \pm 1.2$ \\
WBC, 1000/ $\mu \mathrm{L}$ & $11.5 \pm 4.0$ \\
Platelet, $*$ 1000/ $\mu \mathrm{L}$ & $207.4 \pm 52.6$ \\
\hline &
\end{tabular}

Results are reported as n (\%) or mean \pm standard deviation. NRS, Numeral Rating Scale; NSAID, Nonsteroidal anti-inflammatory drug; WBC, White Blood Cell.

\begin{tabular}{ll}
\hline Table 2. Outcome of sore throat treatment. & Table 2. Outcome of sore throat treatment. \\
\hline Outcomes & All $(\mathrm{n}=40)$ \\
Sore throat at 24 hours, NRS & $3.0 \pm 1.9^{*}$ \\
Treatment response, & \\
Non-responder & $4(10.0)$ \\
Partial responder & $9(22.5)$ \\
Responder & $27(67.5)$ \\
Fever at 24 hours $(\mathrm{n}=39)$ & $3(7.5)$ \\
Fever at 48 hours $(\mathrm{n}=23)$ & $5(12.5)$ \\
Infection event, including pneumonia, after treatment & $0(0.0)$ \\
\hline
\end{tabular}


Results are reported as n (\%) or mean \pm standard deviation. NRS, Numeral Rating Scale. *Statistically significant compared to sore throat at admission $(p$-value $<0.001)$

\begin{tabular}{|c|c|c|c|c|c|c|c|}
\hline $\begin{array}{l}\text { Table } 3 . \\
\text { Univari- } \\
\text { ate and } \\
\text { multi- } \\
\text { variate } \\
\text { analyses } \\
\text { of covari- } \\
\text { ables } \\
\text { associ- } \\
\text { ated } \\
\text { with } \\
\text { treat- } \\
\text { ment } \\
\text { response. }\end{array}$ & $\begin{array}{l}\text { Table 3. } \\
\text { Univari- } \\
\text { ate and } \\
\text { multi- } \\
\text { variate } \\
\text { analyses } \\
\text { of covari- } \\
\text { ables } \\
\text { associ- } \\
\text { ated } \\
\text { with } \\
\text { treat- } \\
\text { ment } \\
\text { response. }\end{array}$ & $\begin{array}{l}\text { Table } 3 . \\
\text { Univari- } \\
\text { ate and } \\
\text { multi- } \\
\text { variate } \\
\text { analyses } \\
\text { of covari- } \\
\text { ables } \\
\text { associ- } \\
\text { ated } \\
\text { with } \\
\text { treat- } \\
\text { ment } \\
\text { response. }\end{array}$ & $\begin{array}{l}\text { Table 3. } \\
\text { Univari- } \\
\text { ate and } \\
\text { multi- } \\
\text { variate } \\
\text { analyses } \\
\text { of covari- } \\
\text { ables } \\
\text { associ- } \\
\text { ated } \\
\text { with } \\
\text { treat- } \\
\text { ment } \\
\text { response. }\end{array}$ & $\begin{array}{l}\text { Table 3. } \\
\text { Univari- } \\
\text { ate and } \\
\text { multi- } \\
\text { variate } \\
\text { analyses } \\
\text { of covari- } \\
\text { ables } \\
\text { associ- } \\
\text { ated } \\
\text { with } \\
\text { treat- } \\
\text { ment } \\
\text { response. }\end{array}$ & $\begin{array}{l}\text { Table } 3 . \\
\text { Univari- } \\
\text { ate and } \\
\text { multi- } \\
\text { variate } \\
\text { analyses } \\
\text { of covari- } \\
\text { ables } \\
\text { associ- } \\
\text { ated } \\
\text { with } \\
\text { treat- } \\
\text { ment } \\
\text { response. }\end{array}$ & $\begin{array}{l}\text { Table } 3 . \\
\text { Univari- } \\
\text { ate and } \\
\text { multi- } \\
\text { variate } \\
\text { analyses } \\
\text { of covari- } \\
\text { ables } \\
\text { associ- } \\
\text { ated } \\
\text { with } \\
\text { treat- } \\
\text { ment } \\
\text { response. }\end{array}$ & $\begin{array}{l}\text { Table } 3 . \\
\text { Univari- } \\
\text { ate and } \\
\text { multi- } \\
\text { variate } \\
\text { analyses } \\
\text { of covari- } \\
\text { ables } \\
\text { associ- } \\
\text { ated } \\
\text { with } \\
\text { treat- } \\
\text { ment } \\
\text { response. }\end{array}$ \\
\hline & $\begin{array}{l}\text { Univariate } \\
\text { analysis }\end{array}$ & $\begin{array}{l}\text { Univariate } \\
\text { analysis }\end{array}$ & $\begin{array}{l}\text { Univariate } \\
\text { analysis }\end{array}$ & & $\begin{array}{l}\text { Multivariate } \\
\text { analysis }\end{array}$ & $\begin{array}{l}\text { Multivariate } \\
\text { analysis }\end{array}$ & $\begin{array}{l}\text { Multivariate } \\
\text { analysis }\end{array}$ \\
\hline $\begin{array}{l}\text { Variable } \\
\text { Symptoms }\end{array}$ & OR & $95 \%$ CI & $p$-value & & OR & $95 \%$ CI & $p$-value \\
\hline $\begin{array}{l}\text { Duration of } \\
\text { symptoms } \\
\text { before } \\
\text { admission }\end{array}$ & 1.79 & 0.93 to 3.46 & .079 & & & & \\
\hline $\begin{array}{l}\text { Sore } \\
\text { throat at } \\
\text { admission }\end{array}$ & 1.16 & $\begin{array}{l}0.80 \text { to } \\
1.67\end{array}$ & .424 & & & & \\
\hline $\begin{array}{l}\text { Body } \\
\text { temperature }\end{array}$ & 0.94 & $\begin{array}{l}0.43 \text { to } \\
2.02\end{array}$ & .876 & & & & \\
\hline Myalgia & 0.29 & $\begin{array}{l}0.03 \text { to } \\
2.72\end{array}$ & .279 & & & & \\
\hline Cough & 0.20 & $\begin{array}{l}0.04 \text { to } \\
1.06\end{array}$ & .058 & & 0.02 & $\begin{array}{l}0.01 \text { to } \\
0.40\end{array}$ & .010 \\
\hline Nausea & 0.33 & $\begin{array}{l}0.08 \text { to } \\
1.37\end{array}$ & .129 & & & & \\
\hline $\begin{array}{l}\text { Physical } \\
\text { exam }\end{array}$ & & & & & & & \\
\hline $\begin{array}{l}\text { Tonsilar } \\
\text { swelling } \\
\text { Grade 3-4 } \\
\text { vs. Grade } \\
0-2\end{array}$ & 0.89 & 0.21 to 3.69 & .871 & & & & \\
\hline $\begin{array}{l}\text { Tonsilar } \\
\text { exudate } \\
\text { Treatment }\end{array}$ & 1.55 & $\begin{array}{l}0.35 \text { to } \\
6.88\end{array}$ & .560 & & & & \\
\hline $\begin{array}{l}\text { NSAID } \\
\text { lozenge } \\
\text { Laboratory } \\
\text { results }\end{array}$ & 0.58 & $\begin{array}{l}0.15 \text { to } \\
2.25\end{array}$ & .435 & & & & \\
\hline
\end{tabular}




\begin{tabular}{|c|c|c|c|c|c|c|c|}
\hline $\begin{array}{l}\text { Table } 3 . \\
\text { Univari- } \\
\text { ate and } \\
\text { multi- } \\
\text { variate } \\
\text { analyses } \\
\text { of covari- } \\
\text { ables } \\
\text { associ- } \\
\text { ated } \\
\text { with } \\
\text { treat- } \\
\text { ment } \\
\text { response. }\end{array}$ & $\begin{array}{l}\text { Table } 3 . \\
\text { Univari- } \\
\text { ate and } \\
\text { multi- } \\
\text { variate } \\
\text { analyses } \\
\text { of covari- } \\
\text { ables } \\
\text { associ- } \\
\text { ated } \\
\text { with } \\
\text { treat- } \\
\text { ment } \\
\text { response. }\end{array}$ & $\begin{array}{l}\text { Table } 3 . \\
\text { Univari- } \\
\text { ate and } \\
\text { multi- } \\
\text { variate } \\
\text { analyses } \\
\text { of covari- } \\
\text { ables } \\
\text { associ- } \\
\text { ated } \\
\text { with } \\
\text { treat- } \\
\text { ment } \\
\text { response. }\end{array}$ & $\begin{array}{l}\text { Table } 3 . \\
\text { Univari- } \\
\text { ate and } \\
\text { multi- } \\
\text { variate } \\
\text { analyses } \\
\text { of covari- } \\
\text { ables } \\
\text { associ- } \\
\text { ated } \\
\text { with } \\
\text { treat- } \\
\text { ment } \\
\text { response. }\end{array}$ & $\begin{array}{l}\text { Table } 3 . \\
\text { Univari- } \\
\text { ate and } \\
\text { multi- } \\
\text { variate } \\
\text { analyses } \\
\text { of covari- } \\
\text { ables } \\
\text { associ- } \\
\text { ated } \\
\text { with } \\
\text { treat- } \\
\text { ment } \\
\text { response. }\end{array}$ & $\begin{array}{l}\text { Table } 3 . \\
\text { Univari- } \\
\text { ate and } \\
\text { multi- } \\
\text { variate } \\
\text { analyses } \\
\text { of covari- } \\
\text { ables } \\
\text { associ- } \\
\text { ated } \\
\text { with } \\
\text { treat- } \\
\text { ment } \\
\text { response. }\end{array}$ & $\begin{array}{l}\text { Table } 3 . \\
\text { Univari- } \\
\text { ate and } \\
\text { multi- } \\
\text { variate } \\
\text { analyses } \\
\text { of covari- } \\
\text { ables } \\
\text { associ- } \\
\text { ated } \\
\text { with } \\
\text { treat- } \\
\text { ment } \\
\text { response. }\end{array}$ & $\begin{array}{l}\text { Table } 3 . \\
\text { Univari- } \\
\text { ate and } \\
\text { multi- } \\
\text { variate } \\
\text { analyses } \\
\text { of covari- } \\
\text { ables } \\
\text { associ- } \\
\text { ated } \\
\text { with } \\
\text { treat- } \\
\text { ment } \\
\text { response. }\end{array}$ \\
\hline Hemoglobin & 2.36 & $\begin{array}{l}0.85 \text { to } \\
6.55\end{array}$ & .099 & & & & \\
\hline
\end{tabular}

OR, Odds ratio; CI, Confidence interval; NSAID, Nonsteroidal anti-inflammatory drug.

Table 4. Treatment response according to the degree of cough. Table 4 . Treatment response according to

Treatment response $(+)$, No. $(\%)$

$13(86.7)$

Results are reported as n (\%). No., Number. 